\title{
Mimicry Marketing Strategy on Marketing Performance of Small and Medium Enterprise
}

\author{
Suliyanto \\ Fakulty of Economic and Business Jenderal Soedirman University \\ suli_yanto@yahoo.com
}

\begin{abstract}
The background of this research is the failure of the marketing orientation concept and the unprepared consumers to accept the societal marketing concept. There needs orientation phase that are between the marketing orientation phase and societal marketing phase. The orientation phase is Adaptive Marketing Orientation (AMO).One of the applications of adaptive marketing orientation is Mimicry Marketing Strategy (MMS). The purpose of this study is to analyze the effect of MMS to competitors, MMS to consumers, MMS to suppliers, MMS to intermediarieson the quality of relationship with partners and innovation as well as to analyze the influence of the quality of relationship with partners and innovation to the marketing performance. Samples are 100 SMEs in Banyumas; data analysis tool used is Path Analysis. The results of this study found that the effect of MMS to consumers and MMS to competitors have positive effect on innovation and the quality of relationship with partners, while MMS to suppliers, and MMS to intermediarie shave no positive effect on innovation and the quality of relationship with partners, and the quality of relationship with partners and innovations have positive effect toward marketing performance.
\end{abstract}

Keywords: Mimicry Marketing Strategy, Innovation, Quality of Relationship with Partners, Marketing Performance, Small and Medium Enterprises

\section{INTRODUCTION}

As the business environment changes rapidly, the marketing orientation concept views that consumers prefer products that suit the needs and desires of consumers; it is not enough to achieve superior marketing performance. It is evident from some of the results of previous studies, namely Pelham (1997) suggests that market orientation is not a positive influence on growth in sales and market share; Deshpande et al., (2000) suggests that market orientation has no effect on the growth and market share, while research conducted by Harris (2001), also concludes that the market orientation has no influence on sales growth measured by both subjective and objective measurements. The amount of research that failed to prove the effect of market orientation on performance marketing shows that, the ability to create products that fit the needs and desires of consumers is not enough to achieve superior performance under conditions of intense competition and very dynamic business environment.

Based on the failure of the marketing concept, it then appears the societal marketing concept developed by Kotler in 1976. The societal marketing orientation views that consumers prefer products that can meet the needs, the desires of consumers and also are able to provide the expected satisfaction more effective and efficient than competitors in a way to maintain and improve the welfare of consumers and the public at large. One of the application forms of societal marketing concept is green marketing, the strategy of mainstreaming environmental considered into all dimensions of marketing activities of the company (Crane, 2000). Although public attention to environmental issues continues to increase, the green marketing strategy as one of the applications of societal marketing has not been able to be the top choice of consumers in Indonesia, even in developed countries. Some researchers also stated that green marketing is not able to increase the competitive advantage (Straughan\& Roberts, 1998; Vlosky et. al., 1999). According to Peattie (1999) green marketing is simply seen as a rhetorical course than substance.

Based on the failure of a marketing orientation and unprepared application of social marketing orientation, it is necessary to know that the orientation phase is between stages of marketing orientation and societal marketing orientation, that is Adaptive Marketing Orientation (AMO). The orientation viewing the consumers toprefer products can meet the needs and desires of consumers, and are marketed in a manner 
consistent with the character of consumers and in accordance with the environmental conditions. This is because consumers not only have different perception of the product, price, distribution channels and promotion but also face different environmental conditions that need a marketing approach that is also different.

Under conditions of a very dynamic environment, where the intensity of the increasingly fierce competition, market and technology turbulence are very quick, the marketing strategy of adaptive traditional relationship marketing is not enough to be relied on to win the competition, so it needs a more personalized and comprehensive adaptive marketing strategy, not just to adjust to the market and competitors.

This more personalized and comprehensive adaptive marketing strategy is called Mimicry Marketing Strategy (MMS), the way to win the competition and the market by adjusting behavior physically and well behaved to the micro environment (customers, competitors, suppliers, intermediaries) and to the macro environment (the intensity of competition, market and technology turbulence). This strategy is different from the adaptive sales concept that was first developed by Spiro and Weitz (1990) which was later developed by Franke and Park (2006); Jaramillo et al., (2007), Roman, and Iacobucci (2010). Mimicry Marketing Strategy (MMS) is not only adapting to sales approach on consumer, but also the placement oneself in the position of competitors, suppliers and intermediaries as well as adapting to the intensity of competition, markets and technology turbulence.

The relationship between the concept of Mimicry Marketing Strategy (MMS), the innovation, the quality of relationship with partners and marketing performance is based on the results described below. Innovation is the mechanism of the company to adapt to the dynamic environment. Ussahawanitchakit (2007) states that the company which is more innovative in the face of competitive environment will have better business performance. This can happen due to the innovation. The organization itself can move forward therefore it can seize the existing opportunities faster or be able to overcome the problem of the organization better. In the end, the organization can work more efficient and effective than its competitors. Innovation is very important in the organization, as stated by Chandra and Neelankavil (2008) who stated that innovation is the best activity. It creates a core value and a competitive weapon for companies, while O'Cass and Ngo (2011) stated that innovation is an important issue of company performance by developing new products.

In a highly dynamic environment, innovation has a very important role to improve marketing performance. There has been a lot of research showing clearly that innovation has a positive impact on competitive advantage and organizational performance. Chen et al., (2009) stated that innovation has a positive effect on competitive advantage. This research was supported by Noorani (2014) who stated that the innovation of the company gives influence to the achievement of competitive advantage. While Aydin et al., (2007) stated that the product innovation by improving the image and reputation of the products will improve performance. Whereas Hoonsopon and Ruenrom (2012) stated that product innovation has a positive effect on company performance. Yeh and Chen (2007) also stated that the higher the level of innovation results in higher organization performance.

According Sya'roni and Sudirham(2012), innovation can be measured to company's ability indicators for the creation of new products and processes, product development, process improvement and adding creative touches with duplicate or guiding production factors as well as new methods.

Relation with partners is a form of relationship marketing. Relationship marketing can be defined as marketing activities that are directed to a strong and sustainable relationships on every individual involved (Wu and Lu, 2012). Relationship marketing is a marketing concept that is oriented in the fabric of a harmonious relationship in long term with all stakeholders (Baumard et al., 2013; Grönroos, 2011). Relationship marketing can be a business-to-business relationship that is the relationship between the company and suppliers, companies with distributor, with similar companies, between whole salers and retailers, as it has been investigated by (Johnsonet al., 2012; Rauyruen and Miller, 2007; Ryding, 2010) and can be either businessto-customer relationship as it has been investigated by Adjeidan Clark 2010 and Mascarenhaset al., 2007. This is in line with the opinion of Gounaris (2005); Slevitch and Oh (2010), which describes the relationship between these networks which can involve consumers, manufacturers, suppliers, intermediaries and other stakeholders.

Several studies have shown that relationship marketing positively affect competitive advantage and company performance. Research conducted by Ngugi et al., (2010) stated that the relational ability with dimension of human relational between employees, suppliers and customers is used by them (the companies) to create value in the eyes of customers and improve their position, while Sin et al., (2006) stated that relationship management has a positive effect on performance marketing. Tsai et al., 2010; Hittet al., 2003, explained that the cooperation relations between these companies will create economic value for the company. Ndubisi (2007) states that the marketing relationship will increase consumer loyalty, while research Grissemannet al., 2013 found the influence of the orientation of customer relationship beyond the influence of innovation and innovative behavior on the performance of financial and non-financial of companies. $\mathrm{Wu}$ and $\mathrm{Lu}, 2012$ states implementation 
of customer relationship management positively affect the relationship marketing and also on company performance.

Dimensions used to measure the relationship marketing by Ndubisi (2007) is a sense of trust, commitment, communication and the ability to handle conflict, whereas Sin et al., (2006) developed six dimensions of the concept of relationship management. All six dimensions comprising: trust, bonding, communication, share value, empathy, and reciprocity.

Performance marketing is part of the organization performance. Organizational performance can be seen from the marketing, financial and human resource performance. Measurement of marketing performance is very important for the marketing performance of organizations because it can be used as information for decision makers of all marketing activities that have been performed (Verhoefet al., 2010), while according Saekoo et al., (2012) states that marketing performance is key to the success of a business as a result of the marketing strategies used for customer, market, and financial benefits for the organization.

Performance by Avlonitis and Salavou (2007) can be grouped into two: the financial performance and marketing performance perceptional. Marketing performance perceptional is marketing performance measured based on the perception of sales growth: the growth of employees and the company's market share compared with its competitors.

Some researchers measure performance by using several dimensions. Davis et al., (2010) stated thatto measure marketing performance can also be used by using the company's profit ability and business growth in a given period. Gama, (2011) measures marketing performance by using the dimension of market share, service quality, customer satisfaction, customer loyalty and brand equity. Chang et al., (2012) measures marketing performance with four perspectives, namely: financial perspective, customer perspective, internal process perspective and the perspective of learning and innovation. While Saekoo et al., (2012) measures marketing performance by using dimension of sales, growth in market share and market development.

Yildız and Caracas (2012) says that the criteria in determining marketing performance can be measured by two approaches, namely objectively and subjectively. Performance measured in this study is either by determining the qualitative criteria, (eg customer satisfaction overall business performance) or quantitative criteria (eg, profits, sales).

In general, the Small and Medium Enterprises (SMEs) have a marketing problem. It stated by Urata (2000) that the problems faced by SMEs can be grouped into two: financial and non-financial problems, one of the problems of non-financial is a marketing problem. Kuncoro (2006) also stated that the problems of SMEs can be grouped into two: internal issues and external issues, one of the internal problems in SMEs is marketing. The low marketing performance on SMEs and the failure of a marketing orientation and unprepared consumers in receiving societal marketing orientation, the adaptive marketing strategy needs to be tested by applying it both on the micro environment (customers, competitors, suppliers, intermediaries) and the macro environment (the intensity of competition, markets and technologies turbulence), the strategy is Mimicry Marketing Strategy (MMS) on SMEs.

\section{METHOD}

Based on the results of previous research, hypothesis can be formulated as followed:

Hyphothesis 1a; 1b; 1c; and 1d:

a) MMS towards consumers,

b) MMS towards competitors,

c) MMS towards suppliers and

d) MMS towards intermediaries have positive effecton innovation.

Hyphothesis 2a; 2b; 2c; and 2d:

a) MMS towards consumers,

b) MMS towards competitors,

c) MMS towards suppliers, and

d) MMS towards intermediaries have positive effect on the quality of relationship with partner.

Hyphothesis 3a; and 3b:

a) Innovation, and

b) The quality of relationship with partner have positive effect on marketing performance.

This study is a survey research. Researchers do not provide treatment to the subjects studied, while based on the time dimension, this study is a cross-section research for data collection is done only once at a time (Suliyanto, 2006). The population in this study is SMEs in Banyumas. It is because the marketing performance of SMEs in Banyumas has yet improved (Suliyanto 2009). The measurement of sample is determined by using the Slovin formula and obtained a sample size of 100 SMEs. With a relatively homogeneous population characteristic, the technique of sampling has been done randomly. The data used in this study are primary data which was obtained directly from the source of research (Cooper and Schindler, 2006). For all variables studied, the authors make a statement by using a Likert scale of 7 , where 1 is strongly disagree to the statement to number 7 for the value of strongly agree. The validity test instrument is obtained by using the product moment correlation, while reliability test is obtained by using Cronbach alpha. To test the hypothesis, path analysis is used. Measurement indicators in this study can be found in Appendix 1. 


\section{RESULTS}

Based on the results of the survey obtained, a description of the characteristics of respondents can be seen as Table 1. Based on the gender of respondents, this research consisted of $56 \%$ of male respondents and $44 \%$ of women respondents.

Table 1. Respondent based on Gender

\begin{tabular}{ccc}
\hline \multicolumn{2}{c}{ Gender } & Total Respondent (\%) \\
\hline Man & 56 \\
Woman & 44 \\
\hline \multicolumn{2}{c}{ Total } & 100 \\
\hline \multicolumn{3}{c}{ Table 2. Respondent based on Age Group } \\
\hline Age & Total Respondent & Average Business Age \\
Group & $\mathbf{( \% )}$ & (Year) \\
\hline $23-30$ & 19 & 5,29 \\
$31-35$ & 8 & 7,33 \\
$36-40$ & 16 & 8,14 \\
$41-45$ & 13 & 13,43 \\
$46-50$ & 22 & 12,48 \\
$>50$ & 22 & 17,08 \\
\hline Total & 100 & 11,09 \\
\hline
\end{tabular}

Based on Table 2 is known that SMEs in Banyumas vary from age group, although it is still dominated by the age of 46 years old and above. However, there is a tendency of entrepreneur from a younger age group ranging from 23-30 years old who start to dive in to the business world, especially the SME sector.

Seeing the age of their business, SMEs in Banyumas had an average age of 11.09 years of business. And if it is related to the average age of the business, it is directly proportional to the age group of respondent. The older the respondent is, the longer the average age of its business. From these data, it is also showed that the age of the respondent in opening a business for the first time was approximately at the age of 32 .

Table 3. Respondent based on Level of Education

\begin{tabular}{cc}
\hline Level of Education & Total Respondent (\%) \\
\hline Elementary School & 19 \\
Junior High School & 12 \\
Senior High School & 62 \\
Diploma/Bachelor & 17 \\
\hline Total & 100 \\
\hline
\end{tabular}

Based on Table 3, it can be seen that the average SMEs in Banyumas are senior high school graduates. There are also elementary school graduates. Similarly, college graduates (Diploma/Bachelor) are still not in the role of SMEs in Banyumas.

The validity testis used to measure the indicator validityin a research questionnaire. The validity test of this research is using product moment correlation formula by comparing the value of $r$ count $r$ table at the $95 \%$ confidence level.

Validity test performed on a sample of 30 respondents, therefore $\mathrm{df}=30-2=28$ with a onesided test. In the table of product moment, $r_{\text {table }}$ is obtained by 0.374 . Based on the calculation results, it can be seen that the entire value of $r_{\text {count }}>r_{\text {table }}$ and a positive value or significance level ( 1 tip) $\stackrel{<}{<} 0.05$, therefore it can be concluded that all indicators of variables of mimicry towards consumers, mimicry towards competitors, mimicry towards suppliers, mimicry towards intermediaries, innovation, quality and performance relationship marketing are declared valid and can be used as a research instrument.

Reliability testing in this study was measured by a statistical test of Cronbanch's Alpha by testing as many as 30 questionnaires. Questionnaires declared reliable if Cronbanch's Alpha $>0.600$. Reliability test was conducted on the variables of mimicry towards consumers, mimicry towards competitors, mimicry towards suppliers, mimicry towards intermediaries, innovation, quality of relationships and marketing performance.

Table 4. Questionnaire Reliability Testing Results

\begin{tabular}{|c|c|c|c|}
\hline Variable & Cronbach's Alpha & $\mathbf{r}_{\text {table }}$ & Explanation \\
\hline $\begin{array}{c}\text { Mimicry } \\
\text { towards } \\
\text { Consumers }\end{array}$ & 0.934 & 0.600 & Reliable \\
\hline $\begin{array}{c}\text { Mimicry } \\
\text { towards } \\
\text { Competitors }\end{array}$ & 0.898 & 0.600 & Reliable \\
\hline $\begin{array}{l}\text { Mimicry } \\
\text { towards } \\
\text { Suppliers }\end{array}$ & 0.871 & 0.600 & Reliable \\
\hline $\begin{array}{l}\text { Mimicry } \\
\text { towards }\end{array}$ & 0.915 & 0.600 & Reliable \\
\hline Intermediaries & & & \\
\hline Innovation & 0.927 & 0.600 & Reliable \\
\hline $\begin{array}{c}\text { Quality of } \\
\text { Relationship }\end{array}$ & 0.926 & 0.600 & Reliable \\
\hline $\begin{array}{c}\text { Marketing } \\
\text { Performance }\end{array}$ & 0.955 & 0.600 & Reliable \\
\hline
\end{tabular}

Based on Table 4 of questionnaire reliability testing, it is shown that Cronbach's Alpha variable of mimicry towards consumers, mimicry towards competitors, mimicry towards suppliers, mimicry towards intermediaries, innovation, quality of relationships and marketing performance is (more than) $>0.600$, therefore it can be concluded that any indicators or questions on all variables used otherwise reliable and can be used as a research instrument.

Based on the first research path analysis model, that is the influence of Mimicry towards Consumer, Mimicry 
Table 5: First Research Path Analysis Model Results

\begin{tabular}{|c|c|c|c|c|}
\hline $\begin{array}{c}\text { Independent } \\
\text { Variable }\end{array}$ & $\begin{array}{c}\text { Path } \\
\text { Coefficient }\end{array}$ & $\begin{array}{c}\mathrm{t} \\
\text { Statistic }\end{array}$ & Sig. & Conclusion \\
\hline $\begin{array}{c}\text { Mimicry } \\
\text { towards } \\
\text { Consumers }\end{array}$ & 0.322 & 2.331 & 0.022 & Significant \\
\hline $\begin{array}{c}\text { Mimicry } \\
\text { towards } \\
\text { Competitors }\end{array}$ & 0.244 & 2.076 & 0.040 & Significant \\
\hline $\begin{array}{l}\text { Mimicry } \\
\text { towards } \\
\text { Suppliers }\end{array}$ & 0.199 & 1.623 & 0.108 & Insignificant \\
\hline $\begin{array}{c}\text { Mimicry } \\
\text { towards } \\
\text { Intermediaries }\end{array}$ & 0.071 & 1.623 & 0.557 & Insignificant \\
\hline \multicolumn{3}{|c|}{ Dependent Variable: Innovation } & & \\
\hline $\mathrm{R}^{2}$ & 0.594 & & & \\
\hline $\mathrm{F}_{\text {count }}$ & 38.767 & & & \\
\hline
\end{tabular}

towards Competitors, Mimicry towards Suppliers, Mimicry towards Intermediaries on Innovation, the results are as Table 5 .

Based on the output of the first research model, it can form the equation of the influence of Mimicry towards Consumers, Mimicry towards Competitors, Mimicry towards Suppliers, Mimicry towards Intermediaries on Innovation. The equation is as followed:

$$
\begin{aligned}
Y_{1}= & 0.322 \mathrm{X}_{1}+0.244 \mathrm{X}_{2}+0.199 \mathrm{X}_{3}+0.071 \mathrm{X}_{4}+ \\
& 0.637 \mathrm{e}
\end{aligned}
$$

In the sub-structure of the first research, we concluded that mimicry towards consumer, and mimicry towards competitors effect on innovation, however mimicry towards suppliers and mimicry towards intermediary have no effect on innovation. This can be explained that if SMEs make adjustments to the consumer and the competitors, it will encourage innovation. Meanwhile, there is no significant relationship between mimicry towards suppliers and intermediaries to innovation because the intensity of the relationship between SMEs with suppliers and intermediaries have a low level of intensity and routine therefore it can also encourage innovation.

Based on the second research path analysis model that is the influence of Mimicry towards Consumers, Mimicry towards Competitors, Mimicry towards Suppliers, Mimicry towards Intermediaries on the Quality of Relationship with Partners, it can form a result as described Table 6 .

Based on the output of the second research model, it can form the equation of the influence of Mimicry towards Consumers, Mimicry towards Competitors, Mimicry towards Suppliers, Mimicry towards Intermediaries on the Quality of Relationship with Partners. The equation is as followed:

$$
\begin{aligned}
\mathrm{Y}_{2}= & 0.491 \mathrm{X}_{1}+0.452 \mathrm{X}_{2}+0.009 \mathrm{X}_{3}+0.018 \mathrm{X}_{4}+ \\
& 0.401 \mathrm{e}
\end{aligned}
$$

\begin{tabular}{|c|c|c|c|c|}
\hline $\begin{array}{l}\text { Independent } \\
\text { Variable }\end{array}$ & $\begin{array}{c}\text { Path } \\
\text { Coefficient }\end{array}$ & $\begin{array}{c}\mathrm{t} \\
\text { Statistic }\end{array}$ & Sig. & Conclusion \\
\hline $\begin{array}{c}\text { Mimicry } \\
\text { towards } \\
\text { Consumers }\end{array}$ & 0.491 & 5.643 & 0.000 & Significant \\
\hline $\begin{array}{c}\text { Mimicry } \\
\text { towards } \\
\text { Competitors }\end{array}$ & 0.452 & 6.129 & 0.000 & Significant \\
\hline $\begin{array}{l}\text { Mimicry } \\
\text { towards } \\
\text { Suppliers }\end{array}$ & 0.009 & 0.113 & 0.910 & Insignificant \\
\hline $\begin{array}{c}\text { Mimicry } \\
\text { towards } \\
\text { Intermediaries }\end{array}$ & 0.018 & 0.236 & 0.814 & Insignificant \\
\hline \multicolumn{5}{|c|}{ Dependent Variable: Quality of Relationship with Partners } \\
\hline $\mathrm{R}^{2}$ & 0.839 & & & \\
\hline $\mathrm{F}_{\text {count }}$ & 138.531 & & & \\
\hline
\end{tabular}

Table 6: Second Research Path Analysis Model Results

In the sub-structure of the second research, it can be concluded that mimicry towards consumer, and mimicry towards competitors affect relationship with partners, but the mimicry towards suppliers and mimicry towards intermediaries does not affect the relationship with partners. This can be explained that if SMEs make adjustments to the consumer and the competitors, it will be as a whole will improve the quality of relationship with partners. This is because most of the relationship with a partner is relationship with suppliers and competitors, where as no significant relationship between mimicry towards suppliers and intermediaries on the quality of relationship with partners. It is because the intensity of the relationship between SMEs with suppliers and intermediaries have low rank of intensity therefore the increasing adjustment with suppliers and intermediaries cannot improve the overall quality of relationship with the partner.

Path analysis results obtained can be described in the path diagram in Figure 1.

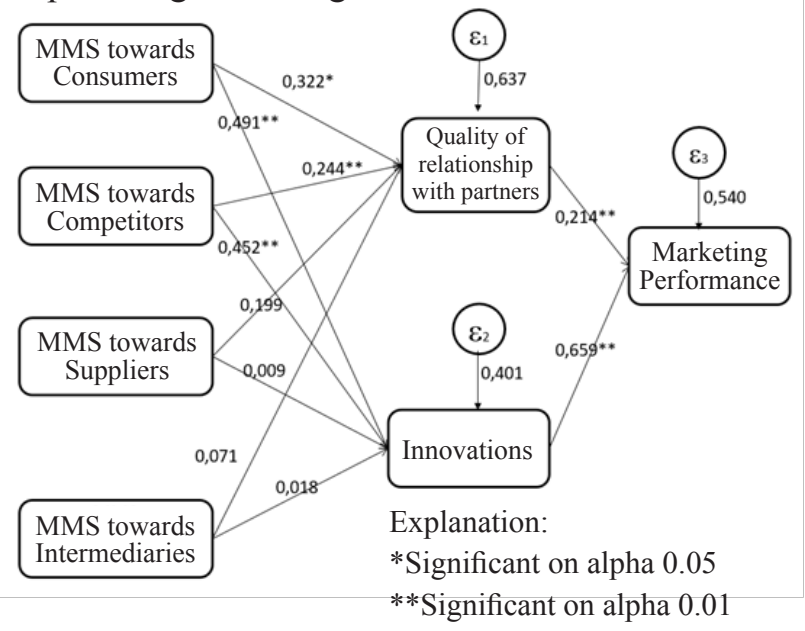

Figure 1: Full Model Path Diagram Analysis on Research Variables Result 
Based on the analysis by using the path diagram, it can be formulated several alternative marketing performance improvements on SMEs as follows:

Alternative 1: MMS towards Consumer $\Rightarrow$ Quality of Relationship with Partner $\Rightarrow$ Marketing Performance.

Alternative 2: MMS towards Consumer $\Rightarrow$ Innovation $\Rightarrow$ Marketing Performance.

Alternative 3: MMS towards Competitor $\Rightarrow$ Quality of Relationship with Partner $\Rightarrow$ Marketing Performance.

Alternative 4: MMS towards Competitor $\Rightarrow$ Innovation $\Rightarrow$ Marketing Performance.

\section{CONCLUSION}

Based on the research and data analysis on SME marketing performance improvement with Mimicry Marketing Strategy (MMS) approach, it can be obtained several conclusions including the following:

1. Mimicry towards consumer factor and mimicry towards competitor factor have positive effect on innovation, while mimicry towards supplierfactor and mimicry towards intermediary factor have no effect on innovation.

2. Mimicry towards consumer factor and mimicry towards competitor factor have positive effect on the quality of relationship with partners, while mimicry towards supplierfactor and mimicry towards intermediary factor does not affect the quality of the relationship with the partner.

3. The quality relationship with partners factor and innovation factor have positive effect on marketing performance.

Based on the conclusions above, it can be recommended that in improving marketing performance for SMEs in Banyumas, they should be able to apply Mimicry Marketing Strategy (MMS) to consumers, and Mimicry Marketing Strategy (MMS) to competitors. How to improve mimicry towards consumers is to appropriately analyze the character of consumers, appropriately analyze the condition of the consumer, emotionally put oneself in the position of consumers, constantly experience on various marketing approaches, use a different marketing approach for each character of consumers, and use a different marketing approach in every condition of different consumer. Meanwhile, this is done to improve mimicry towards competitors by appropriately analyzing the character of competitors, appropriately analyzing the condition of the competitor, emotionally putting oneself in the position of competitors, conducting an experiment to create a market demand that has not been or is not even considered by competitors and do a co-creation with competitors to serve the same customer. For further research, it could develop this research by developing a research model by adding a mediating variable between innovation and the quality of relationship with partners with marketing performance, as well as the need to add environment variables such as the intensity of competition, the turbulence of technology, the changing tastes of the market as a moderating variable between innovation and quality relationships with partners and marketing performance.

\section{BIBLIOGRPHY}

Adjei, M. T., \& Clark, M. N. 2010. Relationship marketing in A B2C context: The moderating role of personality traits. Journal of Retailing and Consumer Services, 17(1), 73-79

Avlonitis, G. J., \&Salavou, H. E. 2007.Entrepreneurial orientation of SMEs, product innovativeness, and performance. Journal of Business Research, 60(5), 566-575

Aydin, S., Cetin, A. T., \& Ozer, G. 2007.The relationship between marketing and product development process and their effects on firm performance. Academy of Marketing Studies Journal, 11(1), 53.

Baumard, N., André, J. B., \& Sperber, D. 2013. A mutualistic approach to morality: The evolution of fairness by partner choice. Behavioral and Brain Sciences, 36(01), 59-78

Chandra, M., \&Neelankavil, J. P. 2008. Product development and innovation for developing countries: potential and challenges. Journal of Management Development, 27(10), 1017-1025.

Chang, S. H., Chen, C. H., \& Ho, Y. C. 2012.A study of marketing performance evaluation system for notebook distributors. International Journal of Business and Management, 7(13), 85.

Chen, Y. S., Lin, M. J. J., \& Chang, C. H. 2009. The positive effects of relationship learning and absorptive capacity on innovation performance and competitive advantage in industrial markets. Industrial Marketing Management, 38(2), 152-158.

Cooper, Donald R. and Schindler, Pamela S., 2006. Bussines Research Methods, 9th edition. McGrawHill International Edition

Crane, A. 2000. Facing the backlash: green marketing and strategic reorientation in the 1990s. Journal of Strategic Marketing, 8(3), 277-296.

Davis, Patrick M.Kreiser and Justin 2010. Entrepreneurial Orientation and Firm Performance : The Unique Impact of Innovativeness, Proactiveness, adn Risk-taking. Journal of Small Business and Entrepreneurship, 23 (1), 39-35.

Deshpande, R.,Farley, J.W and Webster, F.E. 2000. Triad Lessons: Generalizing Results On High Performance Firms In Five Business-Business Markets. International Journal of Research in Marketing, 17.(4), 353-62.

Franke, G. R., \& Park, J.-E. 2006. Salesperson adaptive 
selling behavior and customer orientation: a metaanalysis. Journal of Marketing Research, 43(3), 693-702

Gama, A. P. d. 2011. An expanded model of marketing performance. Marketing Intelligence \& Planning 29 (7):643-661

Gounaris, S. P. 2005. Trust and commitment influences on customer retention: insights from business-tobusiness services. Journal of Business research, 58(2), 126-140

Grissemann, U., Plank, A., \& Brunner-Sperdin, A. 2013. Enhancing business performance of hotels: The role of innovation and customer orientation. International Journal of Hospitality Management, $33,347-356$.

Grönroos, C. 2011. A service perspective on business relationships: The value creation, interaction and marketing interface. Industrial marketing management, 40(2), 240-247

Harris, L.C and Ogbonna, E 2001.Startegic Human Resource Management, Market Orientation, and Organizational Performance.Journal of Business Research, 51(2), 157-66

Hitt, M. A., Ireland, R. D., \& Hoskisson, R. E. 2012. Strategic management cases: competitiveness and globalization. Cengage Learning.

Hoonsopon, D., \&Ruenrom, G. 2012.The impact of organizational capabilities on the development of radical and incremental product innovation and product innovation performance. Journal of Managerial Issues, 250-276.

Jaramillo, F., Locander, W. B., Spector, P. E., \& Harris, E. G. 2007.Getting the job done: the moderating role of initiative on the relationship between intrinsic motivation and adaptive selling. Journal of Personal Selling \& Sales Management, 27(1), 59-74.

Johnson, D. S., Clark, B. H., \& Barczak, G. 2012. Customer relationship management processes: How faithful are business-to-business firms to customer profitability?. Industrial Marketing Management, 41(7), 1094-1105.

Killa, M. F. 2014. Effect of Entrepreneurial Innovativeness Orientation, Product Innovation, and Value Co-Creation on Marketing Performance. Journal of Research in Marketing, 2(3), 198-204.

Kuncoro, Mudrajat. 2006 Usaha Kecil di Indonesia: Profil, MasalahdanStrategi Pemberdayaan.www. mudrajad.com/upload/journal_usaha-kecilindonesia.pdf

Mascarenhas, O. A., Kesavan, R., \& Bernacchi, M. 2006. Lasting customer loyalty: a total customer experience approach. Journal of Consumer Marketing, 23(7), 397-405.

Ndubisi, Nelson, O. 2007. Relationship Marketing and Customer Loyalty. Marketing Intelligence and Planning, 25(10), 98-106.

Ngugi, I. K., Johnsen, R. E., \& Erdélyi, P. 2010.
Relational capabilities for value co-creation and innovation in SMEs. Journal of Small Business and Enterprise Development, 17(2), 260-278.

Noorani, I. 2014. Service innovation and competitive advantage. European Journal of Business and Innovation Research, 2(1), 12-38.

O'Cass, A., \& Ngo, L. V. 2011.Examining the firm's value creation process: a managerial perspective of the firm's value offering strategy and performance. British Journal of Management, 22(4), 646-671.

Peattie, K. 1999. Trappings versus substance in the greening of marketing planning. Journal of Strategic Marketing, 7(2), 131-148.

Pelham A.M 1997. Mediating Influences on the Relationship Between Market Orientation and Profitability in Small Industrial Firms. Journal of Business Research. 45(1), 33-46

Rauyruen, P., \& Miller, K. E. 2007. Relationship quality as a predictor of B2B customer loyalty. Journal of business research, 60(1), 21-31.

Román, S., \& Iacobucci, D. 2010. Antecedents and consequences of adaptive selling confidence and behavior: a dyadic analysis of salespeople and their customers. Journal of the Academy of Marketing Science, 38(3), 363-382.

Ryding, D. 2010. The impact of new technologies on customer satisfaction and business to business customer relationships: Evidence from the soft drinks industry. Journal of Retailing and Consumer Services, 17(3), 224-228.

Saeko, A. N., \&Chuntarung\& Thoumrungroje, P. 2012. The Impact of Integrated Marketing Strategy on Mareting Performance: An Empirical Evidence From Exporting Business in Thailand. International Journal of Business Strategy, 12(4), 56-73.

Sin, L. Y., Alan, C. B., Chan, H., Heung, V. C., \& Yim, F. H. 2006. The effects of relationship marketing orientation on business performance in the hotel industry. Journal of Hospitality \& Tourism Research, 30(4), 407-426.

Slevitch, L., \& Oh, H. 2010. Asymmetric relationship between attribute performance and customer satisfaction: A new perspective. International Journal of Hospitality Management, 29(4), 559-569.

Spiro, R and Weitz, B. 1990. Adaptive Selling: Conceptualization Measurement and Nomiligical Validity. Journal of Marketing Research, 27 (February), 61-69.

Straughan, R. D., \& Roberts, J. A. 1999. Environmental segmentation alternatives: a look at green consumer behavior in the new millennium.Journal of consumer marketing, 16(6), 558-575.

Suliyanto.2006. MetodeRisetBisnis.Penerbit Andi. Yogyakarta.

Suliyanto. 2009. OrientasiPasardanKinerjaPemasaran. LembahManah. Yogyakarta.

Sya'roni, D. A. W., \& Sudirham, J. 2012.Kreativitas dan 
Inovasi Penentu Kompetensi Pelaku Usaha Kecil. Jurnal Manajemen Teknologi, 11(01).

Tsai, H., Cheung, C., \& Lo, A. 2010. An exploratory study of the relationship between customerbased casino brand equity and firm performance. International journal of hospitality management, 29(4), 754-757.

Urata, Shujoro. 2000. Policy Recommendation for SME Promotion in the Republic of Indonesia, JICA Senior Advisor to Coordination Minister of Economy, Finance and Industri. Jakarta

Ussahawannitchakit, P. 2007. Innovation Capability and Export Performance: An Empirical Study of Textile Business in Thailand. International Journal Business Strategy, 7(1), 1- 9

Verhoef, P. C., Venkatesan, R., McAlister, L., Malthouse, E. C., Krafft, M., \& Ganesan, S. 2010. CRM in data-rich multichannel retailing environments: a review and future research directions. Journal of Interactive Marketing, 24(2), 121-137.

Vlosky, Richard P., Ozanne, Lucie K. and Fontenot, Renee J. 1999. A conceptual model of US consumer willingness-to-pay for environmntally certified wood products. Journal of Consumer Marketing, $16(2), 122-136$

Wu, S. I., \& Lu, C. L. 2012. The relationship between CRM, RM, and business performance: A study of the hotel industry in Taiwan. International Journal of Hospitality Management, 31(1), 276-285.

Yeh-Yun Lin, C., \& Yi-Ching Chen, M. 2007. Does innovation lead to performance? An empirical study of SMEs in Taiwan. Management Research News, 30(2), 115-132.

Yıldız, S., dan A. Karakaş. 2012. Defining Methods and Criteria for Measuring Business Performance: A Comparative Research Between the Literature in Turkey and Foreign. Procedia - Social and Behavioral Sciences 58:1091-1102.

\section{APPENDIX}

1. Indicators of Mimicry towards Consumer

a. Being able to appropriately analyze the character of consumer.

b. Being able to appropriately analyze the condition of consumer.

c. Being able to emotionally put oneself in the position of consumer.

d. Always do a trial on a variety of marketing approaches.

e. Being able to use different marketing approach for each character of consumer.

f. Being able to use different marketing approach in every condition of different consumer.

2. Indicators of Mimicry towards Competitor

a. Being able to appropriately analyze the character of competitor. b. Being able to appropriately analyze the condition of competitor.

c. Being able to emotionally put oneself in the position of competitor.

d. Always perform an experiment to create a market demand that has not been or is not even considered by competitors.

e. Being able to do a co-creation with a competitor to serve the same customer.

3. Capabilities of Mimicry towards Supplier

a. Being able toa ppropriately analyze the character of supplier.

b. Being able to analyze the conditions of the supplier (finance, production capacity, experience of the supplier).

c. Being able to emotionally put oneself in the position of the supplier.

d. Being able to create dependency on the supplier company (self-important for suppliers).

e. Being able to strengthen relationships with supplier by maintaining the commitment and willing to share information about new products, promotional programs, the addition of employees, and so that is not confidential.

4. Indicators of Mimicry towards Intermediary

a. Being able to appropriately analyze the character of intermediary.

b. Being able to analyze the condition of intermediary(financial, sales capacity, experience of the intermediary).

c. Being able to emotionally put oneself in the position of intermediary.

d. Being able to create dependency intermediary on the company (theyare important for intermediaries).

e. Being able to use different marketing approach for each character of intermediaries.

f. Being able to use different marketing approaches in any conditions of different intermediaries.

5. Innovation Indicators

a. Always experimenting.

b. Number of new products produced.

c. Number of new services produced.

d. Number of new production processes introduced.

6. Relationship Quality with PartnersIndicators

a. Trust business partners of the company

b. Commitment to business partners

c. The ability to handle conflicts with business partners.

d. The desire to establish a long term relationship.

7. Marketing Performance

a. Achievement of sales targets.

b. The increase in sales volume.

c. The increase in market share.

d. Comparison of volume of sales to competitors. 